\begin{tabular}{|c|c|} 
Available online at: http://ejournal-balitbang.kkp.go.id/index.php/ifrj & e-mail:ifrj.puslitbangkan@gmail.com \\
INDONESIAN FISHERIES RESEARCH JOURNAL & Volume 25 Nomor 2 December 2019 \\
p-ISSN: 0853-8980 & e-ISSN: 2502-6569 \\
Accreditation Number RISTEKDIKTI: 21/E/KPT/2018
\end{tabular}

\title{
BIOLOGICAL REFERENCE POINTS OF PAINTED SPINY LOBSTER Panulirus versicolor (Latreille, 1804) IN KARIMUNJAWA WATERS, INDONESIA
}

\author{
Tri Ernawati ${ }^{\star 1}$, Asep Priatna ${ }^{1}$ and Fayakun Satria ${ }^{1}$ \\ ${ }^{1}$ Research Institute for Marine Fisheries, Ministry of Marine Affairs and Fisheries, Jl. Raya Bogor KM 47, Nanggewer Mekar, \\ Cibinong, Jawa Barat, Indonesia \\ Received; February 02-2018 Received in revised from October 22-2018; Accepted January 07-2019
}

ABSTRACT

\begin{abstract}
A biological reference point is a term used to explain of stock status using a biological approach as a basic of fisheries management. Biological reference points of painted spiny lobster Panulirus versicolor are limited in Karimunjawa waters. This study aims to investigate the stock status of $P$. versicolor and management options to ensure the sustainability of the resources. The research was conducted in Karimunjawa islands of the Java Sea by collecting lobster from local fishers from March to November 2016. A total of 495 lobster were measured, weighed, and their maturity status assessed to allow the size at maturity and selectivity of the fishery to be estimated. The size at maturity $L_{50}(62.2 \mathrm{~mm} \mathrm{CL})$ and $L_{95}(82.0 \mathrm{~mm} \mathrm{CL})$ were larger than $S L_{50}(48.2 \mathrm{~mm} \mathrm{CL})$ and $S L_{95}$ (75.0 mm CL), respectively. Natural mortality $(M)$ which was 0.579 year $^{-1}$ is lower than fishing mortality $(F)$. The current spawning potential ratio (SPR) of $P$. versicolor is $19 \%$ at the current $F$ of 0.82 , which is below SPR limit of $20 \%$ and target reference point of $40 \%$. Hence, to increase SPR level to $40 \%$, the fishing mortality should be reduced by about $40 \%$ to $60 \%$. Closed season, legal size, and defining no take zone are options to consider by fishery manager with appropriate surveillance control. Single or combining those measures can reduce its fishing mortality and take back the stocks to the level of target reference point.
\end{abstract}

\section{Keywords: Painted spiny lobster; size at maturity; mortality; SPR}

\section{INTRODUCTION}

The painted spiny lobster (Panulirus versicolor), locally known as the bamboo lobster, is one of the most economically important species in Indonesia. Painted spiny lobsters are widely distributed in the Indo-West Pacific from eastern coast of Africa to the Red Sea, Japan, Micronesia, Melanesia, Northern Australia and French-Polynesia (Chan, 1998). In Indonesian waters, they are mainly distributed along the coasts and found in coral or rocky reef areas at depths range of 5-20 m (Milton et al., 2012).

In general, the market demand of all spiny lobster continues to increase (Frisch \& Hobbs, 2012). However, at the same time most of spiny lobster fisheries in the world are considered to be fully exploited or over exploited, indicated by the decline in the wild populations (Phillips \& Melville-Smith, 2006; Verghese et al., 2007). In addition, nationally the spiny lobster stock status within FMA 712 (Java Sea) has over exploited and FMA 714 (Banda Sea) has fully exploited (Suman et al., 2016). Hence, appropriate and effective management for spiny lobster in general is urgent.

One possible approach to manage spiny lobster is through using biological target and limit reference points (BRP). A biological reference point is a term used to explain of stock status using a biological approach. The BRPs integrates assessment the combination of life-history parameters in stock assessment and also fishing mortality into a single index or a single modeling framework (Maunder \& Punt, 2013; Szuwalski et al., 2016).

The spawning potential ratio (SPR) is one of model in BRP to determine stock status. The SPR is a relative rate index of reproduction in an exploited stock. The SPR is commonly used as a target and limit reference point for fisheries (Hordyk et al., 2015a). Its method recommended for applying to stocks in datalimited fisheries (Brooks et al., 2010). The concept of SPR is a proportion of the unfished reproductive potential left by fishing impact. By definition, the population in unfished stock has an SPR of $100 \%$ 
$\left(\mathrm{SPR}_{100 \%}\right)$ and mortality caused by fishing reduces the SPR from the unfished level to SPR $_{x \%}$ (Prince et al., 2015)

Karimunjawa Islands waters are a part of Indonesia's Fisheries Management Area (FMA) 712 (the Java Sea). The islands are designated as national marine park that serves as a marine resource conservation area. Karimunjawa waters is known as a coral reef ecosystem. Based on Yusuf (2013), the condition of most coral reefs in the Karimunjawa National Park was damaged and categorized as medium (25 - 49,9\% cover coral) while coral reefs in a small part of the park were classified as good ( 50 $74,9 \%$ cover coral).
Data on BRP for $P$. versicolor in Karimunjawa waters are very limited. The aim of this study is to describe the stock status of $P$. versicolor through SPR and possible management advice to fishery manager to sustain of this resource.

\section{MATERIALS AND METHODS Data Collection}

A total of 495 lobsters were collected and measured between March and November 2016 in Karimunjawa Islands (Figure 1), consisted of 309 females and 186 males. Lobster fishers in Karimunjawa use small boats $<5 \mathrm{GT}$. The fishers dive to catch the lobsters directly by hand at night.

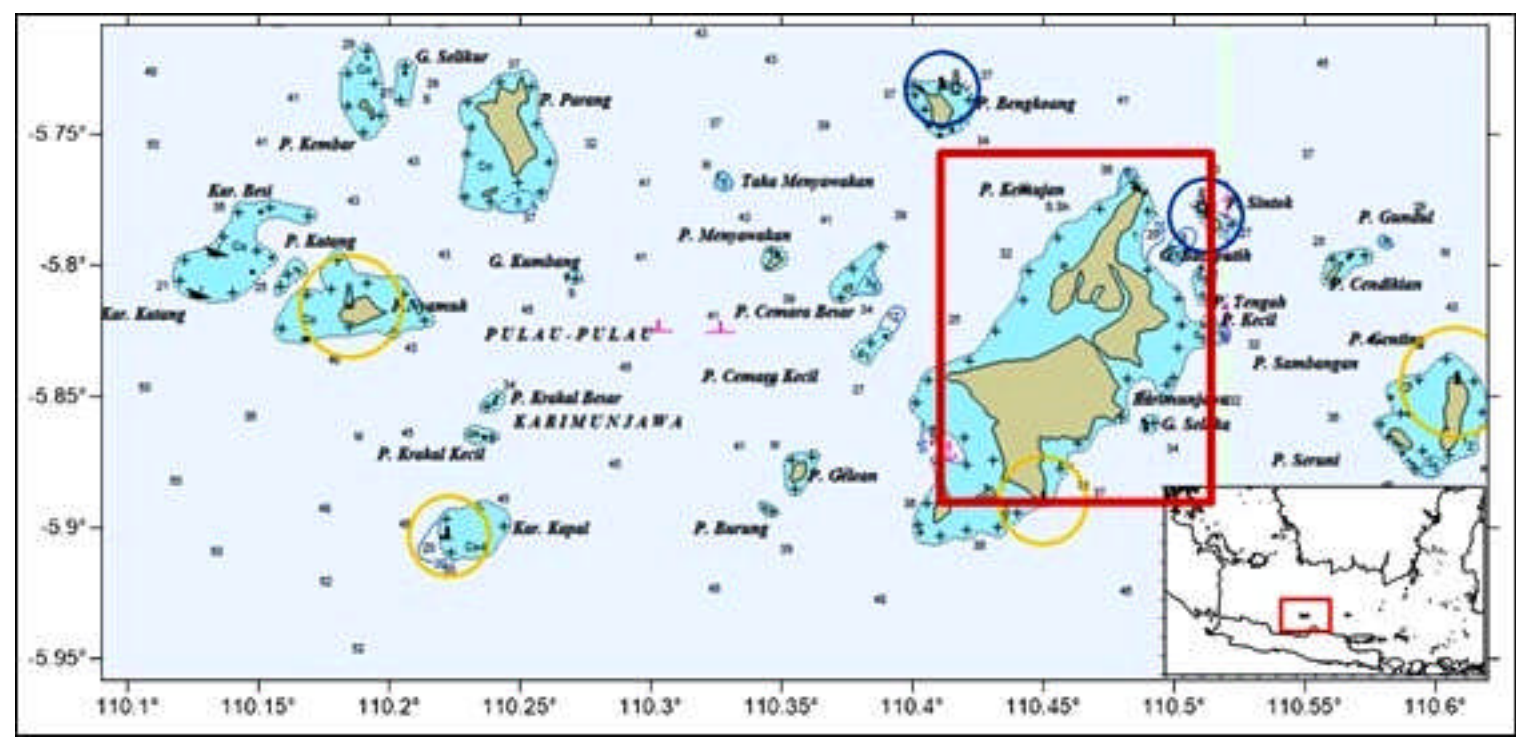

Figure 1. Map of locations of the research on Panulirus versicolor in the Karimunjawa Islands, off the Central Java coast, Indonesia.

All samples were measured and recorded for their carapace length, weight, and stages of ovarian development. Data collections were conducted monthly in private landing sites (collectors). The number of samples that were collected in every month was around 60 lobsters. The ovarian stages of female lobster were determined following Silva \& Cruz-landim (2006):

I. Immature, little forming of the ovaries with slim anterior and posterior lobes is limited to the body cavity, the color of ovaries is white, and difficult to differentiate from encircling muscles.

II. Prematuration, the ovaries are growing in volume and expanded with color is pink or light yellow. The organ seems bloated and tough to the touch.

III. Mature, the gonad is completely developed and will fill all available room in the body cavity. It grows more winding and is able to extend into the second segment of stomach and the color is orange or reddish.

IV. Spawning or resorption, the ovary might be reabsorbed ovulation oocytes and other cells. It is getting soft with pigmented zones and the spaces are internally empty. At this stage, ovary seems in the immature or premature level, though a spawned lobster ovary is not at all fully reinstated the original immature shape.

\section{Data Analyses \\ Carapace-Length Size at Maturity}

The mean of carapace-length at maturity was analyzed by fitting a logistic curve to the proportion of mature females lobster in each size class. The estimation of mean carapace-length of maturity was derived following equation of King (1995): 


$$
P=\frac{1}{(1+\exp \exp (-a(L-L m)))}
$$

Where, $P$ is the proportion of ovarian mature individual by carapace-length $(L)$; $a$ is the slope of the curve; $L_{m}$ is the mean carapace-length at first maturity.

\section{Natural Mortality}

Natural mortality $(M)$ is one of the essential parameters of life-history. By estimating $M$, fishing mortality can be estimated from the age or size composition of commercial or independent-survey catches (Gislason et al., 2010). The estimating of $M$, particularly for data-poor stocks, uses an updated Hoenig method when $t_{\text {max }}$, the maximum age in years, is available, following the formula of Then et al., 2015:

$M=5.109 / t_{\max }$

\section{Growth}

Growth paramater as an input for SPR estimation was obtained by fitting the von Bertalanffy growth function,

$$
L_{t}=L_{,}^{*}\left(1-e^{-k(t-t o)}\right)
$$

Where, $L_{t}$ is the carapace length at the time $t ; L_{\infty}$ is the asymptotic carapace length; $k$ is the growth coefficient; $t$ is the theoretical carapace length at age 0 . The analyses were done using Electronic Length Frequency Analysis (ELEFAN) in TrophFishR packages (Mildenberger et al., 2017). The maximum age $\left(t_{\max }\right)$ can be estimated by growth parameter $k$. The calculation of $t_{\text {max }}$ was defined from Pauly (1980) equation:

$$
t_{\max } \approx 3 / k
$$

\section{Spawning Potential Ratio (SPR)}

SPR is one of biological reference points of determining stock status of a species in the population. The reference points of SPR used are: SPR $20 \%$ is as limit reference point and SPR $40 \%$ is a target reference point (Bunnell \& Miller, 2005; Kilduff et al., 2009; Hordyk et al., 2015a). Estimating SPR needsparameters of life history. The SPR was defined as (Hordyk et al., 2015b):

$$
S P R=\frac{\left.\sum\left(1-\tilde{L}_{x}\right)^{(M / k[(F / M)+1]}\right] \tilde{L}_{x}^{b}}{\sum\left(1-\tilde{L}_{x}\right)^{M / k}} \tilde{L}_{x}^{b} \text { for } x_{m} \leq x \leq 1 . .
$$

Where, $L_{x}$ is carapace length (female lobsters); $M$ is natural mortality; $k$ is growth rate; $F$ is fishing mortality; and $b$ is exponent usually close to 3 . Estimating SPR with those functions need the simple assumptions of asymptotic or logistic selectivity and no variation in length at age.

Based on the equation (5), $F / M$ ratio can be estimated from the length composition of the catch (Hordyk et al., 2015b). The relationship between F/M and SPR is asymptotic and determined by the selectivity parameters. There are many combinations of F/M and selectivity produce similar values of SPR at high fishing pressure (Prince et al., 2015).

As informed above, the lobsters are caught by hand directly, not using any gears, so the size compositions are truncated and also uninformative for estimating the size of full selectivity. To address this issue, an approach following Prince et al. (2015) by bounding the selectivity parameters was adopted.

\section{RESULTS AND DISCUSSION \\ Results}

\section{Carapace-Length at Maturity}

The length of carapace at $50 \%$ maturity for female lobster $\left(L_{m}\right.$ or $\left.L_{50}\right)$ was defined as the size at which $50 \%$ of all female population has entered into a stage of matured (Kizhakudan \& Patel 2010). The $L_{m}$ of $P$. versicolor was estimated to be at $62.2 \mathrm{~mm} \mathrm{CL}$ and the $C L$ at which $95 \%$ of females were mature $\left(L_{95}\right)$ was $82.0 \mathrm{~mm}$ (Figure 2).

\section{The Carapace-Length Distribution}

Based on the carapace-length $(C L)$ distribution of all female lobster caught, about $51 \%$ of painted-spiny lobster were less than the $L_{m}$ of $62.2 \mathrm{~mm}$ (Figure 3). The mean size of spiny lobster was $58.9 \pm 19.4 \mathrm{~mm}$ $C L$, and ranged from $18.4 \mathrm{~mm}$ to $124.2 \mathrm{~mm} \mathrm{CL}$ (Figure 3). 


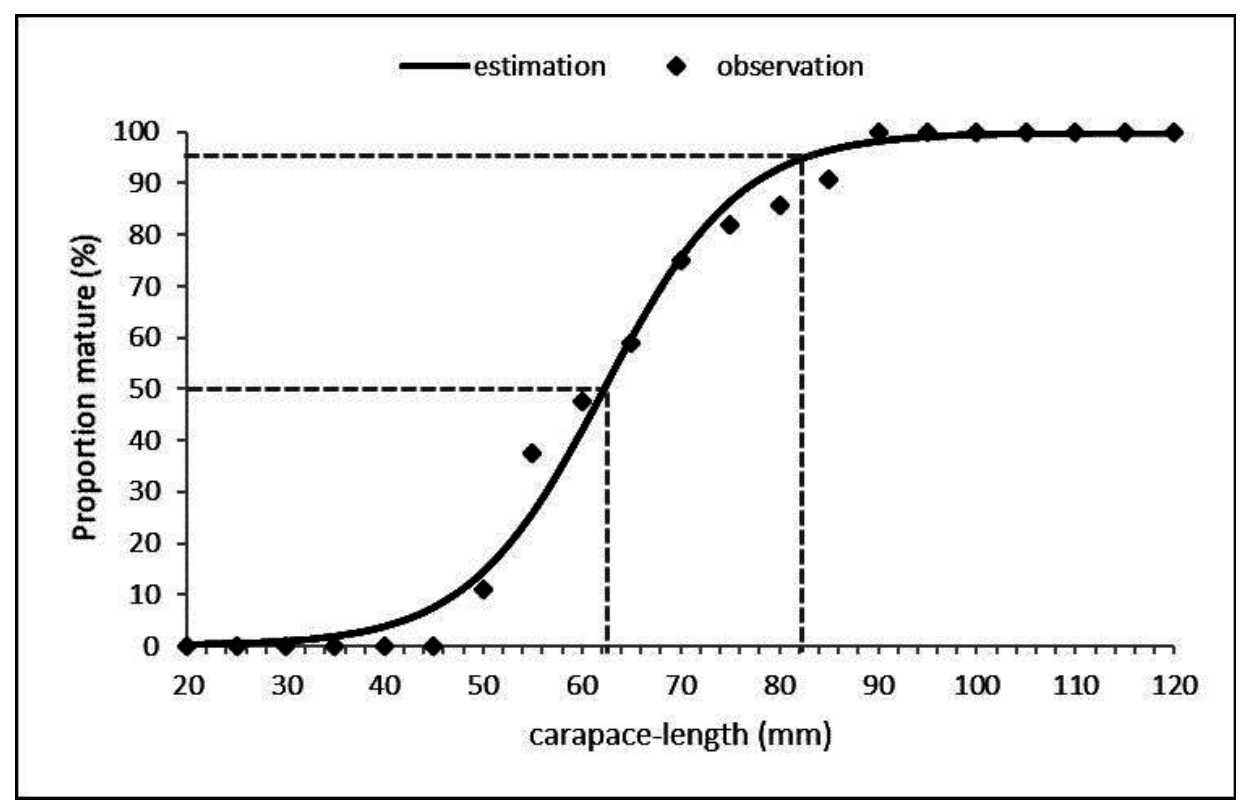

Figure 2. The carapace-length at which $50 \%$ and $95 \%$ of female painted spiny lobster ( $P$. versicolor) are mature $\left(\mathrm{L}_{50}\right.$ and $\left.\mathrm{L}_{95}\right)$ in Karimunjawa waters, Java Sea, Indonesia.

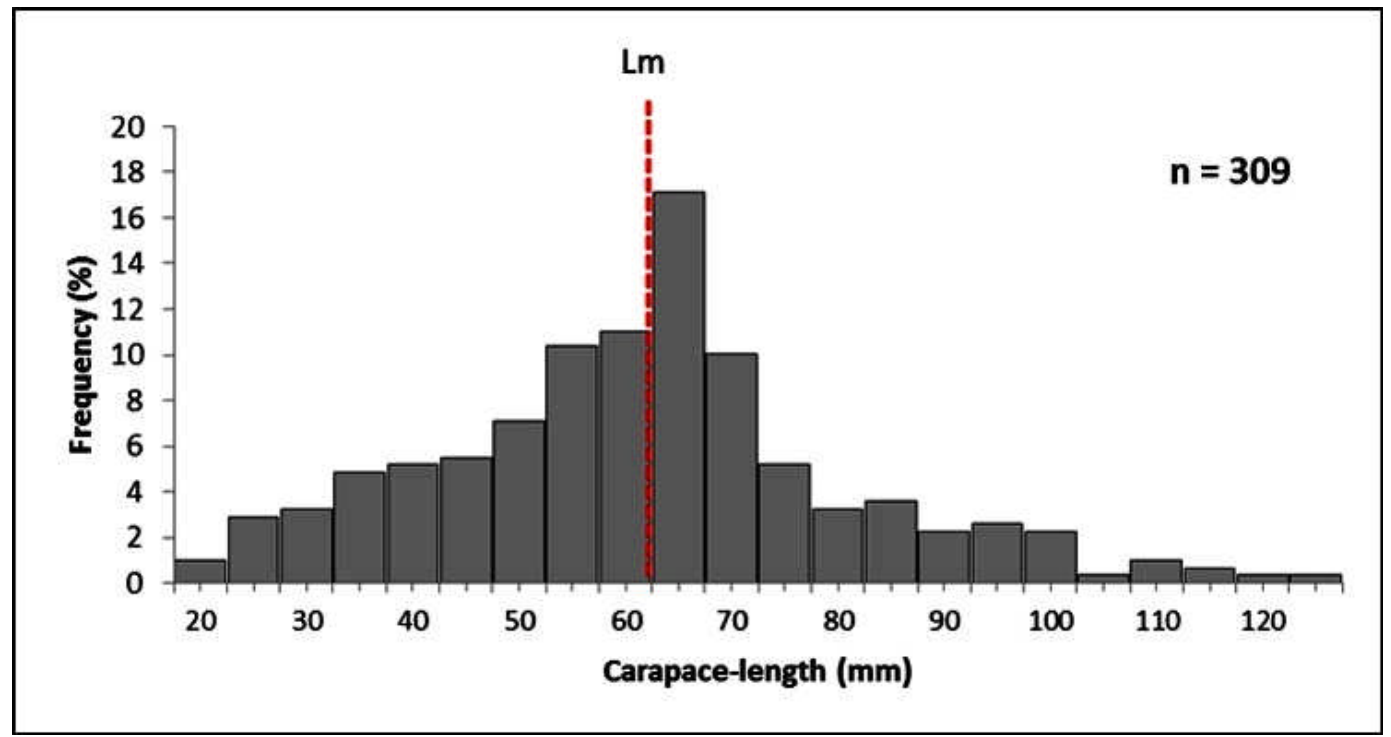

Figure 3. The carapace-length distribution of females $P$. versicolor from Karimunjawa waters. The red line is $L_{m}$ or $L_{50}$.

\section{Growth}

The von Bertalanffy growth model, which basically determines growth as continuous over a time scale has been adjusted to several lobster species. The model was used to account analytical method and other size-based stocks (Cobb \& Caddy, 1989). Figure 4 shows monthly carapace length distributions of combined males and females $P$. versicolor and .Figure 5 shows their fitting of ELEFAN using von Bertalanffy model. The carapace length asymptotic $\left(L_{\infty}\right)$ was acquired at $131 \mathrm{~mm}$. The maximum age was gained at about 8.8 years with relatively slow growth $(k=$ $0.34)$. The carapace-length at first maturity $\left(L_{m}\right)$ for $P$. versicolor in Karimunjawa could be reached at the age of about 2 years (Figure 6 ). 


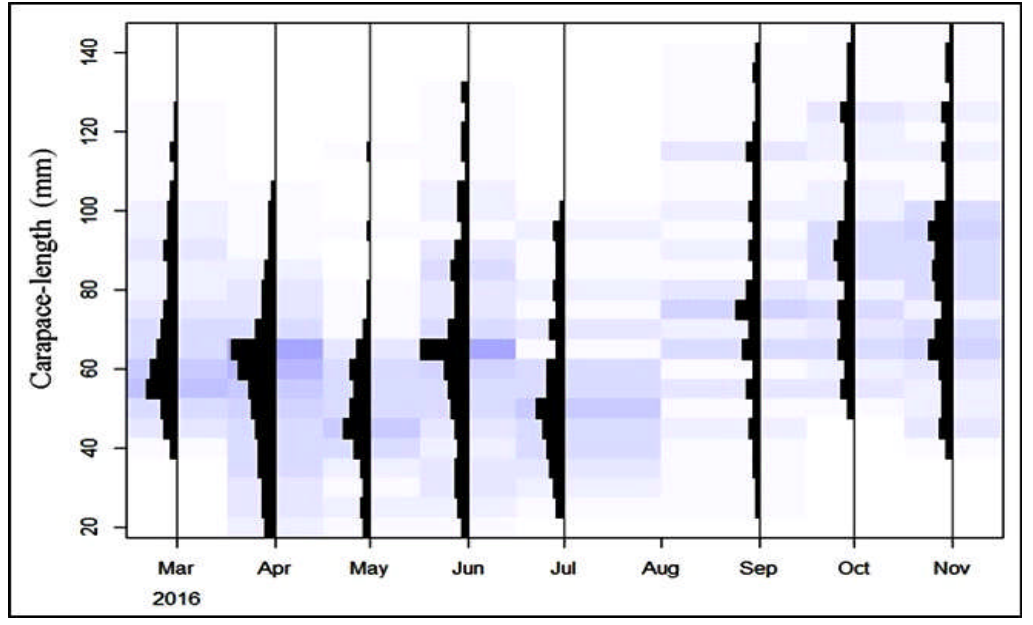

Figure 4. Monthly carapace length frequency distributions of combined males and females $P$. versicolorin Karimunjawa waters.

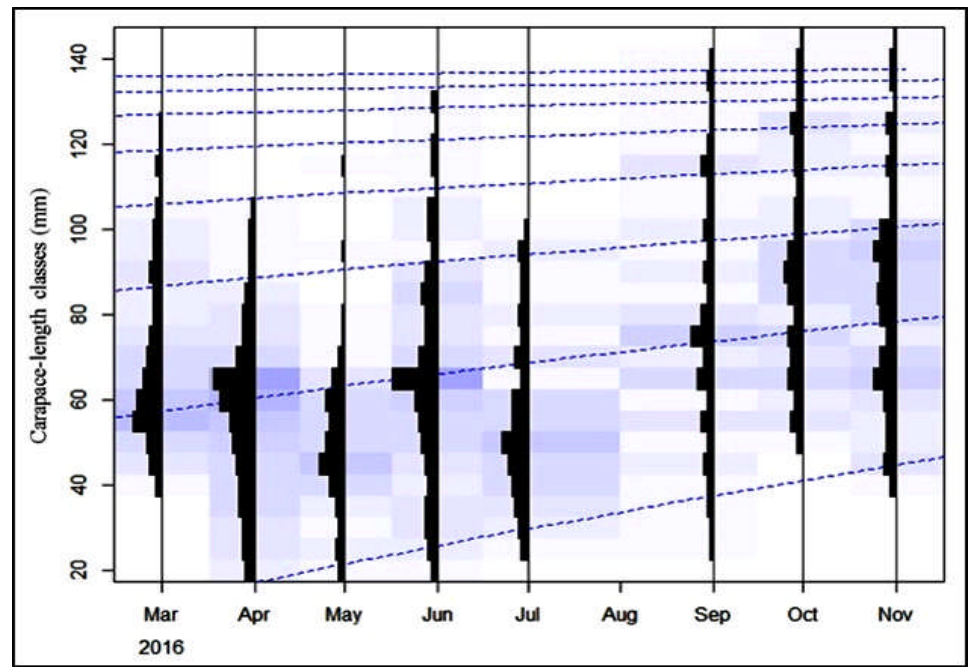

Figure 5. Fitting of ELEFAN based on von Bertalanffy growth model of P.versicolor without separating males and females in Karimunjawa waters.

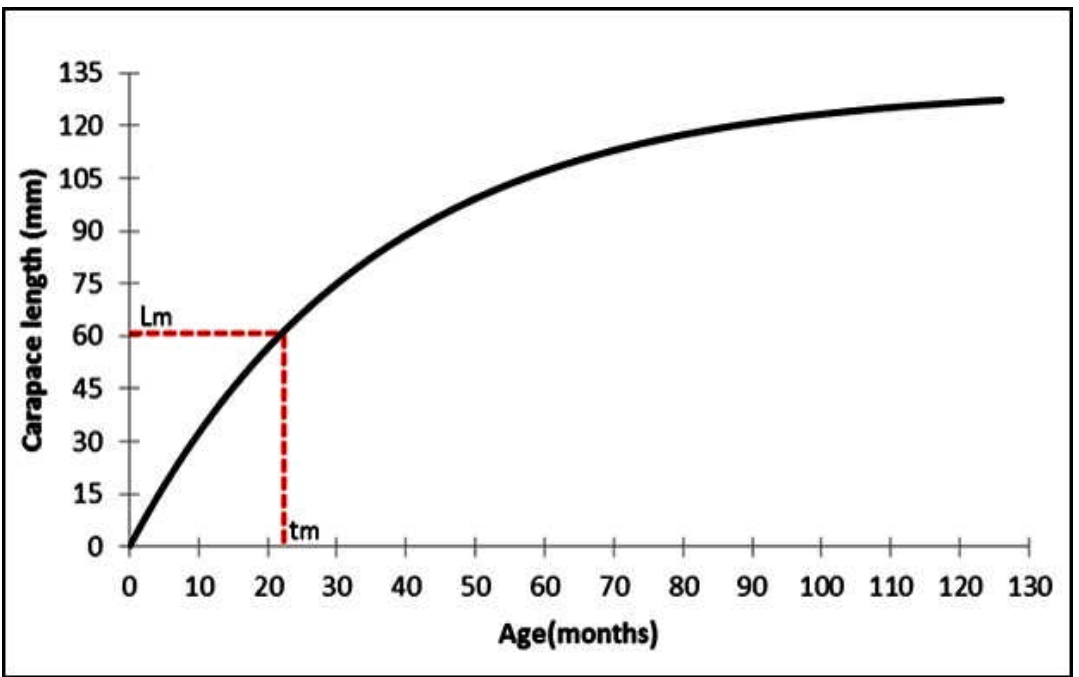

Figure 6. The growth curves of painted spiny lobster $P$. versicolor and age of females first maturity from Karimunjawa waters. 


\section{Mortality and Spawning Potential Ratio (SPR)}

Natural mortality $(M)$ was estimated by using maximum age $\left(t_{\max }\right)$ of $P$. versicolor. Based on $t_{\max }$ of 8.8 years, $M$ of painted spiny lobster was obtained at 0.579 year $^{-1}$. Based on the ratio of $F / M$ at 1.42 , the $F$ (fishing mortality) was 0.82 year $^{-1}$. The ratio of $L_{m} / L_{\text {, }}$ and $M / k$ of lobsters in Karimunjawa were 0.47 and
1.70 , respectively. With these parameters and size composition data, we estimated the $50 \%$ selectivity $S L_{50}=48.2 \mathrm{~mm} \mathrm{CL}$ and $95 \%$ selectivity as $S L_{95}=$ $75.0 \mathrm{~mm}$ CL. From all the parameters, SPR then was obtained at $19 \%$ (Table 2). Target reference point of SPR $40 \%$ was at $F$ level of 0.38 as a proxy value. The correlation of SPR with $F$ is illustrated in Figure 7.

Table 2. The results of spawning potential ratio (SPR), fishing pressure $(F / M)$ and selectivity $\left(S L_{95}, S L_{50}\right)$. $\mathrm{CV}=$ coefficient of variation

\begin{tabular}{lc}
\hline \multicolumn{1}{c}{ Parameters } & Values \\
\hline SPR $(\%)$ & 19 \\
SL50 $(m m$ carapace-length) & 48.2 \\
SL5 (mm carapace-length) & 75.0 \\
F/M & 1.4 \\
CV & 0.1 \\
\hline
\end{tabular}

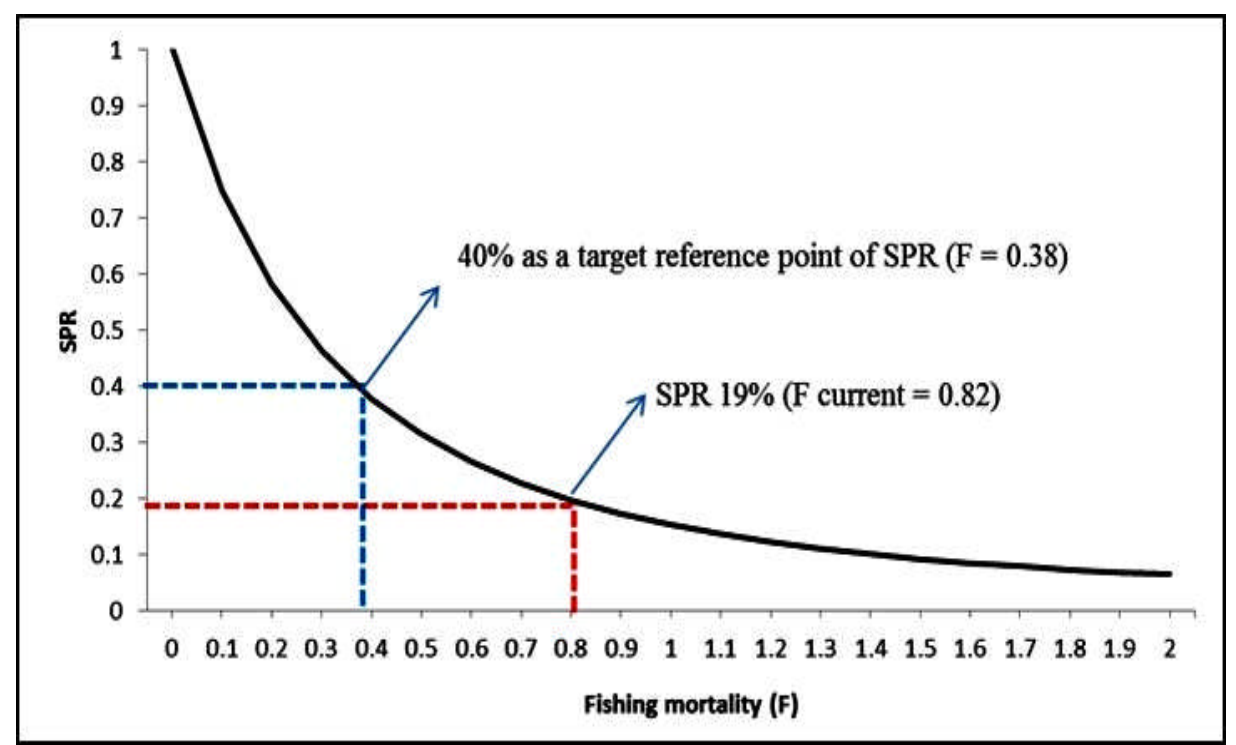

Figure 7. The relationship between Spawning Potential Ratio (SPR) and different levels of fishing mortality for painted spiny lobster $P$. versicolor in Karimunjawa Islands, Java Sea, Indonesia. The estimated fishing mortality for the target SPR of $40 \%$ is also shown.

\section{Discussion}

The mean size at first maturity $\left(L_{m}\right.$ or $\left.L_{50}\right)$ in this study was $62 \mathrm{~mm} C L$. Table 3 shows its comparison to other studies, including the mean size at capture $\left(S L_{50}\right)()$. The difference in mean size at maturity in different areas can be caused by biotic and abiotic environmental variables, such as temperature, population density, food availability, and shelter (Chittleborough, 1976; DeMartini et al., 2003; Chang et al., 2007; Polovina, 1989). In addition, the ability to determine sexual maturity is an essential requirement to accurately identify the maturation state. Among other approaches, the histological method of the oocytes developmental stages is the most accurate method to determine sexual maturity (Chang et al., 2007).
The size at maturity $L_{50}$ and $L_{95}$ were larger than $S L_{50}(48.2 \mathrm{~mm} \mathrm{CL})$ and $S L_{95}(75.0 \mathrm{~mm} \mathrm{CL})$, respectively. This indicated that most of lobsters had not matured yet when they were fished. For the long term, this condition can potentially threaten the sustainability of lobster resources in this area. Common evidence show high fishing pressure can cause smaller size lobster with low quantity and quality of eggs. The worst case scenario is when the lobster populations declining due to less number of brooders and recruitment failure. The $S L_{50}$ of $P$. versicolor lobsters in Karimunjawa waters is similar to ones from the southern West-Java waters, which was $50.0 \mathrm{~mm}$ $C L$ (Nuraini \& Sumiono, 2008). However, this was still smaller than $P$. versicolor lobsters from Flores waters, which was $73.67 \mathrm{~mm} \mathrm{CL}$ (Ernawati et al., 2014). 
Fishing pressure on lobster in the Flores waters to date is still very low. It seems that lobster in Karimunjawa and southern West-Java waters has had higher fishing pressure than lobsters in Flores waters.

Nationally, the minimum legal size of lobsters is regulated for the size at $80 \mathrm{~mm} \mathrm{CL}$ (Regulation Minister of Marine and Fisheries, the Republic of Indonesia No. 56, 2016) for all species of spiny lobsters. Based on the result of length at maturity $\left(L_{m}\right)$ of $P$. versicolor in this study, in the waters of Karimunjawa, it is $~ 75 \%$ smaller than the legislated legal size, similar to the $L_{m}$ for this species in Ekas Bay, Lombok (Table 3). The regulation should be reconsidered, every species of lobster have different characteristics. Therefore, the regulation of minimum size should not be equated for all species of spiny lobsters.

The growth of $P$. versicolor in Karimunjawa waters can be categorized as a slow growth which is shown by the growth coefficient 0.34 year $^{-1}(k<1)$ (Sparre \& Venema, 1999). The variation growth coefficient $(k)$ and carapace length asymptotic $(L$,$) of other Palinurids$ has been reported from previous studies (Table 4).

Table 3. Summary of the estimated size at maturity of the bamboo lobsters $P$. versicolor from different studies and regions. $L_{50}$ or $L_{\mathrm{m}}$ is the mean size at maturity (in $\mathrm{mm} \mathrm{CL}$ ) and $S L_{50}$ is the mean size at capture (in $\mathrm{mm} \mathrm{CL}$ )

\begin{tabular}{|c|c|c|c|c|}
\hline Region & Author & $L_{50}$ or $L_{m}$ & $S L_{50}$ & Method \\
\hline $\begin{array}{l}\text { Great Barrier Reef, } \\
\text { Australia }\end{array}$ & Frisch (2007) & 78 & & $\begin{array}{l}\text { the size of smallest ovigerous } \\
\text { female }\end{array}$ \\
\hline Southern West-Java & Nuraini et al. (2008) & & 50 & logistic function \\
\hline Ekas bay, Lombok & Junaidi et al. (2010) & $61-71$ & & the ovarian development \\
\hline Flores waters & Ernawati et al. (2014) & & 73.67 & logistic function \\
\hline Karimunjawa, Java & This study & 62 & & the ovarian development \\
\hline
\end{tabular}

Table 4. Summary of Palinurids growth parameters from different researches and geographical area.

\begin{tabular}{|c|c|c|c|c|c|}
\hline Region & Species & $\begin{array}{c}L_{\infty} \\
(\mathrm{mm} C L)\end{array}$ & $k$ year $^{-1}$ & $\begin{array}{c}\text { Geography } \\
\text { area }\end{array}$ & Author \\
\hline South Africa & Palinurus gilchristi & $\begin{array}{c}95.75- \\
111.2 \\
\text { (male); } \\
78.5- \\
96.11 \\
\text { (female) }\end{array}$ & $\begin{array}{c}0.05- \\
0.092 \\
\text { (male); } \\
0.065- \\
0.129 \\
\text { (female) }\end{array}$ & temperate & $\begin{array}{l}\text { Groeneveld, } \\
\text { (1997) }\end{array}$ \\
\hline GBR, Australia & Panulirus versicolor & $\begin{array}{c}144.7 \\
185\end{array}$ & $\begin{array}{l}0.27 \\
0.10\end{array}$ & temperate & Frisch, (2007) \\
\hline Western Sardinia & Palinurus elephas & $\begin{array}{c}\text { (male); } \\
116 \\
\text { (female) }\end{array}$ & $\begin{array}{c}\text { (male); } \\
0.16 \\
\text { (female) }\end{array}$ & temperate & $\begin{array}{l}\text { Bevacqua et al. } \\
(2010)\end{array}$ \\
\hline $\begin{array}{l}\text { North-west coast } \\
\text { India }\end{array}$ & $\begin{array}{l}\text { Panulirus } \\
\text { polyphagus }\end{array}$ & $\begin{array}{c}135 \\
\text { (male); } \\
124.7 \\
\text { (female) }\end{array}$ & $\begin{array}{c}0.46 \\
\text { (male); } \\
0.38 \\
\text { (female) }\end{array}$ & tropical & $\begin{array}{l}\text { Kizhakudan et al. } \\
(2013)\end{array}$ \\
\hline $\begin{array}{l}\text { Northern Sikka, } \\
\text { Flores }\end{array}$ & Panulirus versicolor & 146.7 & 0.44 & tropical & $\begin{array}{l}\text { Ernawati et al. } \\
(2014)\end{array}$ \\
\hline Western Aceh & Panulirus homarus & 119.5 & 0.39 & tropical & $\begin{array}{l}\text { Kembaren \& } \\
\text { Nurdin, (2015) }\end{array}$ \\
\hline $\begin{array}{l}\text { Palabuhanratu, } \\
\text { Western Java }\end{array}$ & Panulirus homarus & $\begin{array}{c}110.5 \\
\text { (male); } \\
103.2 \\
\text { (female) }\end{array}$ & $\begin{array}{c}0.29 \\
\text { (male); } \\
0.40 \\
\text { (female) }\end{array}$ & tropical & $\begin{array}{l}\text { Zairion et al. } \\
\text { (2017) }\end{array}$ \\
\hline $\begin{array}{l}\text { Karimunjawa, } \\
\text { Java }\end{array}$ & Panulirus versicolor & 131 & 0.34 & tropical & This study \\
\hline
\end{tabular}


The growth of lobsters as in many crustaceans was impacted by water temperature (Chittleborough, 1975), availability and quality of food (Robertson et al., 2000), salinity (Field \& Butler, 1994), and injury (Hunt \& Lyons, 1986). Overall, the results show that lobsters in tropical waters tend to grow faster than lobsters in temperate waters. These can support the theory that aquatic animals grow faster with decreasing latitude, possibly due to the effects of temperature on metabolism (Heibo et al., 2005). The temperatures in tropical waters are relatively stable and in Karimunjawa waters are generally above $25^{\circ} \mathrm{C}$, while those in temperate waters are fall below $20^{\circ} \mathrm{C}$ during winter, inhibiting metabolism and growth.

Panulirus versicolor mortality was mainly driven by fishing intensity that was indicated by the greater value of $F$ compared to $M$. As fishing intensity can be obtained from the size of catches (Zairion et al., 2017), it was then revealed that the carapace length was dominated at $58.9 \pm 19.4 \mathrm{~mm}$ and mean length at first capture $\left(S L_{50}\right)$ was at $48.2 \mathrm{~mm}$, less than the $L_{\mathrm{m}}$ or $L_{50}$. Hence, this can support the assumption that high fishing intensity occurred in Karimunjawa thus explained why smaller or young lobsters dominate the catch. However, further investigation is needed since fishing activities of lobster fisheries in Karimunjawa waters generally were utilized by diving and catching directly with their hands. Therefore, they have limited capacity to reach the deeper waters. Consequently, fishermen are only able to catch lobsters in shallow waters where younger and smaller lobsters are found (Dennis et al., 1997).

Managers should consider that lobsters and other invertebrates might be difficult to manage because their productivity were closely related to the environmental conditions (Botsford 2001; Linnane et al., 2010). The population of lobsters are frequently resilient to depletion of low biomass (Breen, 1994; Pollock, 1993). Many lobsters are managed using reference points which are less precautionary than that has been estimated (Szuwalski et al., 2016). For example, SPR $10 \%$ and $5 \%$ were used as target for Homarus americanus in the USA and Canada, respectively, and 5\% for Panulirus argus in the USA, but unfortunately recruitment decreases in the 2000s raised questions about these target levels (Caddy, 2004).

The SPR of $P$. versicolor estimated for the Karimunjawa waters of $19 \%$ at the current $F$ of 0.82 , which was slightly under the Limit reference point (LRP) $20 \%$. Hence, to reach the target SPR of $40 \%$, $F$ level should reach 0.38 by reducing the fishing mortality about $40 \%$ to $50 \%$. To reduce fishing mortality, several options can be considered to be forwarded to lobster fishery manager, such as: 1) continuing the socialization and implementation and compliance to reduce the capture of lobster $<62 \mathrm{~mm}$ $C L$ i.e. the $L_{m}, 2$ ) applying closed fishing season for lobster during lobster recruitment phase where the scientific advice available, and 3) Karimunjawa nationally is designated for conservation area then might be expanded as well for its lobster habitat as no take zones. The fishery manager can consider the social and economic impacts on the local fishers when considering the potential measures to apply. For the third option, it is the most appropriate way to rebuild the stock for reducing the fishing mortality. As a conservation area, itwill be not complicated in the surveillance.

\section{CONCLUSION}

The $L_{50}, S L_{50}$, ratio of fishing to natural mortality $(F / M)$, and SPR as biological reference points can be used to determine the stock status for painted spiny lobster. The size at maturity $\left(L_{50}\right)$ was $\sim 25 \%$ longer than the mean length at capture $\left(S L_{50}\right)$. This indicated that most of lobsters had not matured before they were fished. Fishing mortality $F$ was greater than natural mortality $M$. It means that most of mortality is caused by fishing intensity. Stock status of painted spiny lobster in Karimunjawa waters was just below the SPR limit reference point of $20 \%$. Thus, management actions are needed if the SPR is to be increased above the limit reference point and shift the SPR of this stock towards the target reference point of $40 \%$. Reducing the fishing intensity about $50 \%$ is required to achieve the SPR level above the LRP. Therefore, this is an appropriate management measure at national level, while continuing on current legal size with strong implementation and enforcement. Aclosed fishing season and no take zone for Karimunjawa are also possible options to consider by fishery manager while the socio-economic impacts of these measures need to be considered as well.

\section{ACKNOWLEDGEMENTS}

TE has contributed mainly to this work. AP and FS are supporting contributor to this work. This research is part of Stock Assessment of Fisheries Resources in Java Sea (Fisheries Management Area 712) Project in 2016, supported by Research Institute for Marine Fisheries, funded by Indonesia national budgeting (DIPA 2016). The authors thank Drs. Isa Nagib Edrus for supporting on data collection in Karimunjawa. 


\section{REFERENCES}

Bevacqua, D., Melia, P., Follesa, M.C., DeLeo, G.A., Gatto, M., \& Cau, A. (2010). Body growth and mortality of the spiny lobster Palinurus elephas within and outside a small marine protected area. Fisheries Research. 106: 543 - 549. doi:10.1016/ j.fishres.2010.10.008.

Verghese, B., Radhakrishnan, E.V., \& Padhi, A. (2007). Effect of environmental parameters on immune response of the Indian spiny lobster, Panulirus homarus (Linnaeus 1758). Fish \& Shellfish Immunology. 23, 928-936. doi:10.1016/ j.fsi.2007.01.021

Botsford, L.W. (2001). Physical influences on recruitment to California current invertebrate populations dynamics on multiple scales. ICES J.Mar.Sci. 58, 1081-1091. doi:10.1006/ jmsc.2001.1085.

Breen, P.A. (1994). Population dynamics and stock assessment of lobsters: a review. Crustaceana. $67,239-255$.

Brooks, E.N., Powers, J.E., \& Cortes, E. (2010). Analytical reference points for age-structured models: application to data-poor fisheries. ICES J. Mar. Sci. 67, 165 - 167. doi: 10.1093/icesjms/ fsp225

Bunnell, D.B., \& Miller, T.J. (2005). An individual-based modeling approach to spawning potential perrecruit models: an application to blue crab (Callinectes sapidus) in Chesapeake Bay. Can J Fish Aqua Sci. 62, 2560-2572, doi: 10.1139/F05153.

Caddy, J. (2004). Current usage of fisheries indicators and reference points, and their potential application to management of fisheries for marine invertebrates. Can. J. Fish. Aquat. Sci. 61, 13071324. doi: 10.1139/F04-132.

Chan, T.Y. (1998). Lobsters. In Carpenter KE, Niem $\mathrm{VH}$ (Eds). FAO Species identification guide for fishery purposes. The living marine resources of the Western Central Pacific. FAO-UN. Vol. 2. Rome. p. 973 - 1043.

Chang, Y.J., Sun, C.L., Chen, Y., Yeh, S.Z., \& Chiang, W.C. (2007). Reproductive biology of the spiny lobster, Panulirus penicillatus in the southern coastal waters of Taiwan. Mar. Biol. 151, 553-564. doi 10.1007/s00227-006-0488-9.
Chittleborough, R.G. (1976). Breeding of Panulirus longipes Cygnus George under natural and controlled conditions. Aust. J. Mar. Freshw. Res. 27:499-516. doi:10.1071/MF9760499

Chittleborough, R.G. (1975). Environmental factors affecting growth and survival of juvenile Western Rock Lobsters Panulirus longipes (Milne-Edwards). Aust. J. of Mar. Freshw. Res. 21, 944-951. doi: 10.1071/MF9750177.

Cobb. J.S., \& Caddy, J.F. (1989). The population biology of decapods (p. 327-344). In: Caddy JF (Ed.) Marine invertebrate fisheries. Wiley and Sons. New York, US.

DeMartini, E.E., DiNardo, G.T., \& Williams, H.A. (2003). Temporal changes in population density, fecundity and egg size of the Hawaiian spiny lobster, Panulirus marginatus, at Necker Bank, Northwestern Hawaiian Islands. Fish. Bull. 101, 22-31.

Dennis, D.M., Skewes, T.D., \& Pitcher, C.R. (1997). Habitat use and growth of juvenile ornate rock lobsters, Panulirus ornatus (Fabricius 1798), in Torres Strait. Aust. J. of Mar. Freshw. Res. 48: 663 - 670. doi: 10.1071/MF97184.

Ernawati, T., Kembaren, D.D., Suprapto., \& Sumiono, B. (2014). Population parameters of painted spiny lobster (Panulirus versicolor) in Northern Sikka and adjacent waters. BAWAL. 6 (3): $169-175$. (in Indonesian).doi:10.15578/bawal.6.3.2014.169-175

Field, J.M., \& Butler IV, M.J. (1994). The influence of temperature, salinity and postlarval transport on distribution of juvenile spiny lobsters, Panulirus argus (Latreille, 1804), in florida Bay. Crustaceana. Vol. 67, No. 1, Proceedings of the Fourth International Workshop on Lobster Biology and Management.pp. $26-45$.

Frisch, A.J. (2007). Growth and reproduction of the painted spiny lobster (Panulirus versicolor) on the Great Barrier Reef) Australia. Fisheries Research, 85, 61 -67. doi:10.1016/j.fishres.2006.12.001.

Frisch, A.J. \& Hobbs, J.A. (2012). Demography, fishery yield and potential management strategies of painted spiny lobster (Panulirus versicolor) at Northwest Island, Great Barrier Reef, Australia. Mar. and Fresh. Res. 63: 387-396. http:// dx.doi.org/10.1071/MF11241 
Gislason, H., Daan, N., Rice, J.C., \& Pope, J. (2010). Size, growth, temperature and the natural mortality of marine fish. Fish and Fisheries, 11, 149-158. doi:10.1111/j.1467-2979.2009.00350.x.

Groeneveld, J.C. (1997). Growth of spiny lobster Palinurus gilchristi (Decapoda:Palinuridae) off South Africa. South African Journal of Marine Science. 18(1), 19-29. doi: 10.2989/ 025776197784160983.

Heibo, E., Magnhagen, C., \& Vollestad, L.A. (2005). Latitudinal variation in life-history traits in Eurasian perch. Ecology. 86, 3377-3386. doi: 10.1890/041620.

Hordyk, A., Ono, K., Valencia, S., Loneragan, N., \& Prince, J. (2015a). A novel length-based empirical estimation method of spawning potential ratio (SPR), and test of its performance, for small-scale, data-poor fisheries. ICES J.Mar. Sci. 72: 204-216 doi: 10.1093/ icesjms/fsu004, 1-15.

Hordyk, A., Ono, K., Sainsbury, K., Loneragan, N., \& Prince, J.D. (2015b). Some explorations of the life history ratios to describe length composition, spawning-per-recruit, and the spawning potential ratio. ICES J.Mar. Sci. 72: 217-231 doi: 10.1093/ icesjms/fst235.

Hordyk, A., Loneragan, N., \& Prince, J.D. (2015c). An evaluation of an iterative harvest strategy for data-poor fisheries using the length-based spawning potential ratio assessment methodology. Fisheries Research. 171, 20-32, dx.doi.org/ 10.1016/j.fishres.2014.12.018.

Hunt, J.H., \& Lyons, W.G. (1986). Factors affecting growth and maturation of spiny lobsters, Panulirus argus, in the Florida Keys. Can. J. of Fish. \& Aqu. Sci. 43: 2243-2247. doi:10.1139/f86-275.

Junaidi, M., Cokrowati, N., \& Abidin Z. (2010). Reproduction aspects of lobsters (Panulirus sp) in Ekas Bay Lombok island waters. J. Kelautan. 3 (1), 29-35. (in Indonesian). doi:10.21107/ jk.v3i1.839

Kembaren, D.D., \& Nurdin, E. (2015). Distribution of the size and parameters of the population of Green scalloped rock lobster (Panulirus homarus) in the waters of West Aceh. BAWAL, 7, 121-128. doi: 10.15578/bawal.7.3.2015.121-128

Kilduff, P., Carmichael, J., \& Latour, R. (2009). Guide to fisheries science and stock assessments.
Atlantic State Marine Fisheries Commission. NOAA.76p.

King, M. (1995). Fisheries biology, assessment and management (p. 341). Fishing news book. Oxford, UK.

Kizhakudan, J.K., \& Patel, S.K. (2010). Size at maturity in the mud spiny lobster Panulirus polyphagus (Herbst 1793). J. Mar. Biol. Ass. India, $52(2), 170-179$.

Kizhakudan, J.K., Shoba, J.K., \& Patel, S.K. (2013). Growth and moulting in the mud spiny lobster, Panulirus polyphagus (Herbst, 1793). Indian. J. Fish, 60 (2), $79-86$.

Linnane, A., Gardner. C., Hobday, D., Punt, A., McGarvey, R., Feenstra, J., \& Matthews, J. (2010). Evidence of large-scale spatial declines in recruitment patterns of southern rock lobster Jasus edwardsii, across south-eastern Australia. Fisheries Research, 105, 163-171. doi: 10.1016/ j.fishres.2010.04.001.

Maunder, M.N., \& Punt, A.E. (2013). A review of integrated analysis in fisheries stock assessment. Fisheries Research. 142: 61 - 74. doi:10.1016/ j.fishres.2012.07.025.

Mildenberger, T.K., Taylor, M.H., \& Wolff, M. 2017. TropFishR: an $\mathrm{R}$ package for fisheries analysis with length-frequency data. Methods in Ecology and Evolution 8:1520-1527.

Milton, D.A., Proctor, C., Satria, F., \& West, R.J. (2012). South coast Java lobster fishery. (p.46). Report prepared for ACIAR Project FIS/2006/142, Developing new assessment and policy frameworks for Indonesia's marine fisheries, including the control and management of illegal, unregulated and unreported (IUU) fishing. Austarlian National Centre for Ocean Resources and Security (ANCORS), University of Wollongong, Australia.

Nuraini, S., \& Sumiono, B. (2008). Parameters biology of lobsters in coastal Pangandaran Jawa Barat. Proceedings of the Annual National Seminar V Results Fisheries and Marine Research. Gadjah Mada University: 14p. (in Indonesian).

Pauly, D. (1980). On the interrelationships between natural mortality, growth parameters and mean environmental temperature in 175 fish stocks. J. Cons. CIEM 39(3). 175-92. 
Phillips, B.F., \& Melville-Smith, R. (2006). Panulirus species. In 'Lobsters: Biology, Management, Aquaculture and Fisheries' (p. 359-384). Ed. B. F. Phillips. Oxford: Blackwell Publishing.

Pollock, D.E. (1993). Recruitment overfishing and resilience in spiny lobster populations. ICES J. Mar. Sci. 50(1): 9 - 14. doi:10.1006/ jmsc.1993.1002.

Polovina, J.J. (1989). Density dependence in spiny lobster, Panulirus marginatus, in the Northwestern Hawaiian Islands. Can. J. Fish. Aquat. Sci, 46 (4), 660-665. doi.org/10.1139/f89-084.

Prince, J., Hordyk, A., Valencia, S.R., Loneragan, N., \& Sainsbury K. (2015a). Revisiting the concept of Beverton - Holt life history invariants with the aim of informing data poor fisheries assessment. ICES J. Mar. Sci, 72, 194-203. doi:10.1093/icesjms/ fsu011, 1-10.

Prince, J., Victor, S., Kloulchad, V., \& Hordyk A. (2015b). Length based SPR assessment of eleven Indo-Pacific coral reef fish populations in Palau. Fisheries Research, 171, 42-58. doi:10.1016/ j.fishres.2015.06.008.

Robertson, D.N., Butler, M.J., \& Dobbs, F.C. (2000). An evaluation of lipid and morphometric based indices of nutritional condition for early benthic stage spiny lobsters, Panulirus argus. Marine and Freshwater Behavior and Physiology. 33: 161-171. doi:10.1080/10236240009387088

Silva, J.R.F., \& Cruz-Landim, C. (2006). Macroscopic aspects and scanning electron microscopy of the ovaries of the spiny lobsters Panulirus
(Crustacea:Decapoda). Braz. J. morphol. Sci. 23(3-4): $479-486$.

Sparre, P., \& Venema, S.C. (1999). Introduction of tropical fish stock assessment, Book 1: Manual (p. 438). Center for Fisheries Research and Development. Jakarta.

Suman, A., Irianto, H.E., Satria, F., \& Amri, K. (2016). Potency and exploitation rate of fish resources in Indonesia Fisheries Management Areas 2015 also management options. J. Kebijakan. Perik. Ind, 8(2), 97-110. (in Indonesian). doi: 10.15578/ jkpi.8.2.2016.97-100

Szuwalski, C.S., Castrejon, M., Ovando, D. \& Chasco B. (2016). An integrated stock assessment for red spiny lobster (Panulirus penicillatus) from the Galapagos marine reserve. Fisheries Research. 177: 82 - 94. doi:10.1016/j.fishres.2016.01.002

Then, A.Y., Hoenig, J.M., Hall, N.G., \& Hewitt, D.A. (2014). Evaluating the predictive performance of empirical estimators of natural mortality rate using information on over 200 fish species. ICES J.Mar. Sci. doi: 10.1093/ icesjms/fsu36, 1-11.

Yusuf, M. (2013). Condition of Coral Reef and Fish Potential in Karimunjawa National Park Waters, Regency of Jepara. Bul. Osea. Mar. 2:54-60. (in Indonesian).

Zairion., Islamiati, N., Wardiatno, Y., Mashar, A., Wahyudin, R.A. \& Hakim, A.A. (2017). Population dynamics of scalloped spiny lobster (Panulirus homarus Linnaeus 1758) in Palabuhanratu waters, west Java. J. Pen. Perik. Ind. 23: 215-226. (in Indonesian).doi: 10.15578/jppi.23.3.2017.215-226. 